\title{
KESESUAIAN INSTRUMEN PERKULIAHAN INTENSIVE READING TERHADAP KERANGKA KUALIFIKASI NASIONAL INDONESIA
}

\author{
Sri Handayani ${ }^{1}$, Luqman Alhakim ${ }^{2}$ \\ ${ }^{(1,2)}$ Pendidikan Bahasa Inggris, Universitas Slamet Riyadi \\ E-mail: Jihandayani.2017@gmail.com ${ }^{1}$, luqman.hakim76@gmail.com²
}

\begin{abstract}
ABSTRAK
Penelitian ini bertujuan untuk mengidentifikasi kesesuaian Instrumen perkuliahan Intensive Reading terhadap Kerangka Kualifikasi Nasional Indonesia untuk program pendidikan bahasa Inggris di Universitas Slamet Riyadi. Jenis penelitian ini adalah content analysis. Temuan penelitian menunjukkan bahwa (1) penggunaan metode pembelajaran yang relevan untuk perkuliahan Intensive Reading masih belum bervariasi karena dosen cenderung menggunakan metode ceramah, skimming, dan scanning, (2) dosen cenderung mengadopsi materi pembelajaran tidak otentik, yaitu buku cetak sehingga perlu menggunakan kedua bahan otentik dan otentik, (3) hasil belajar didasarkan pada kurikulum meskipun belum ditulis aspek afektif, (4) pengalaman belajar kurang bervariasi karena penggunaan ruang kelas sebagai tempat untuk memberikan kuliah. (5) struktur rencana pembelajaran semester (RPS) sudah memuat 9 kriteria minimal yang sudah dipenuhi oleh RPS mata kuliah Intensive Reading, dan (6) Substansi RPS mata kuliah Intensive Reading sudah mencakup seluruh standar yang disebutkan didalam Peraturan Presiden (PP) no 8 tahun 2012 tentang kerangka kualifikasi nasional Indonesia dan Peraturan Menteri Riset, Teknologi, dan Pendidikan Tinggi (Permenristekdikti) No 44 tahun 2015.
\end{abstract}

Kata Kunci: Mata Kuliah Intensive Reading, KKNI, Konten Analisis

\begin{abstract}
The research aims at identifying the appropriateness between the instruments of Intensive Reading course and Indonesia national qualification framework of English Language Education Program at Slamet Riyadi University. The type of research is content analysis. The research findings show that (1) the use of relevant learning methods for the course is unvaried because the lecturer tends to use a lecturing, skimming, and scanning methods, (2) the lecturer tends to use inauthentic learning materials (printed book); therefore it needs to use both authentic and inauthentic materials, (3) the learning result is based on the curriculum although it is not written affective aspect yet, (4) the students' learning experience are unvaried because the use of a classroom as single room for the course, (5) the structure of the lesson plan has contained 9 criteria as required by the regulation of the ministry of research, technology, and higher education No 44 year 2015, and the substance of the lesson plans has comprised the whole standard required in the President regulation (PP) no 8 year 2012 about Indonesia National Qualification Framework dan the regulation of the ministry of research, technology, and higher education No 44 year 2015.
\end{abstract}

Keywords: Intensive Reading Course, Indonesia National Qualification Framework, Content Analysis 


\section{PENDAHULUAN}

Globalisasi dan revolusi industri diseluruh lini kehidupan menyebabkan penyesuaian aktifitas manusia untuk menyelaraskan kehidupan dengan era tersebut. Kompetensi seseorang untuk menghadapi persaingan di era tersebut menuntut Pemerintah Pusat untuk menyusun kebijakan yang selaras untuk menunjang keberlangsungan karir seseorang. Pemerintah merumuskan kerangka kualifikasi nasional Indonesia untuk memetakan karir dan keahlian seseorang untuk mampu bersaing di era globalisasi dan revolusi industry 4.0. Dirjen Kemendikbud (2014) menyatakan bahwa Kerangka kualifikasi adalah instrumen untuk menentukan jenjang kualifikasi berdasarkan deskripsi CP. Deskripsi tersebut merupakan alat untuk memetakan keahlian dan karir seseorang, serta mengembangkan kurikulum pendidikan. CP merupakan pernyataan tentang apa yang diketahui, difahami dan dapat dikerjakan oleh seseorang setelah menyelesaikan proses belajar. Kerangka Kualifikasi Nasional Indonesia merupakan kerangka penjenjangan kualifikasi kompetensi yang dapat menyandingkan, menyetarakan, dan mengintegrasikan antara bidang pendidikan dan bidang pelatihan kerja serta pengalaman kerja.

Program studi Pendidikan Bahasa Inggris Universitas Slamet Riyadi mengikuti kebijakan pemerintah pusat melalui kegiatan revitalisasi kurikulum pada tahun 2015 dan 2017 dan hasilnya adalah tersusunnya kurikulum berbasis KKNI dan telah mengikuti kegiatan Asosiasi Program Studi Pendidikan Bahasa Inggris (APSPBI) sejak tahun 2015 dan telah mengikuti capaian pembelajaran (learning outcomes) sesuai dengan hasil pertemuan APSPBI di Hotel Aria Barito Banjarmasin yaitu tersusunnya dan diputuskannya capaian pembelajaran dan profil lulusan program studi Pendidikan Bahasa Inggris pada jenjang S1 dan S2.

Mata kuliah Intensive Reading merupakan salah satu mata kuliah hasil dari revitalisasi kurikulum program studi pendidikan Bahasa Inggris berbasis KKNI di tahun 2015. Pada kurikulum sebelumnya, mata kuliah ini bernama Reading II. Mata kuliah ini memiliki perangkat pembelajaran berupa seperangkat RPS dan buku ajar berjudul Well Read I. Kenyataannya, peneliti menemukan bahwa buku ajar dan perangkat pembelajaran mata kuliah ini sering berganti sebab menyesuaikan dengan capaian pembelajaran yang dirumuskan oleh APSPBI sehingga diperlukan kajian untuk mengetahui kesesuaikan perangkat pembelajaran terhadap KKNI. Disamping itu, pembinaan softskill mahasiswa melalui kajian tentang pembelajaran sikap pada materi perkuliahan intensive reading diperlukan dalam rangka peningkatan softskill calon lulusan agar memiliki softskill yang cakap untuk menunjang kompetensi professional yang mereka miliki.

Rumusan masalah penelitian ini yang dipaparkan dalam artikel ini adalah bagaimana kesesuaian perangkat pembelajaran mata kuliah Intensive Reading terhadap kerangka kualifikasi nasional Indonesia pada Program Studi Pendidikan Bahasa Inggris tahun akademik 2018/2019. Tujuan dari penelitian ini adalah untuk mengidentifikasi kesesuaian perangkat pembelajaran mata kuliah Intensive Reading terhadap kerangka kualifikasi nasional Indonesia pada Program Studi Pendidikan Bahasa Inggris tahun akademik 2018/2019.

Peraturan Presiden (PP) no 8 tahun 2012 tentang kerangka kualifikasi nasional Indonesia digunakan oleh peneliti dalam menganalisa substansi capaian pembelajaran lulusan dan capaian pembelajaran mata kuliah Intensive Reading. Sedangkan untuk 
struktur dan substansi selain dua hal tersebut dianalisa berdasarkan Peraturan Menteri Riset, Teknologi, dan Pendidikan Tinggi (Permenristekdikti) No 44 tahun 2015.

Dari pemaparan tersebut, penulis melaksanakan riset dengan judul Content Analysis Pada Materi Perkuliahan Intensive Reading Ditinjau Dari Kerangka Kualifikasi Nasional Indonesia (KKNI) (Studi pada Mahasiswa Semester II Program Studi Pendidikan Bahasa Inggris, Universitas Slamet Riyadi, Tahun Akademik 2018/2019).

\section{METODE PENELITIAN}

Jenis penelitian ini adalah penelitian Content Analysis. Menurut Ary, Jacobs, dan Razavieh (2010) bahwa Content or document analysis is a research method applied to written or visual materials for the purpose of identifying specified characteristics of the material. Dengan kata lain bahwa konten atau dokumen analisi merupakan metode penelitian yang diimplementasikan pada materi tertulis atau bergambar untuk tujuan mengidetifikasi karakteristik khusus yang ditemukan pada materi tertentu. Untuk Prosedur Penelitian Studi Kasus Menurut Ary, Jacobs, dan Razavieh (2010) terdapat enam prosedur penelitian analisis dokumen: (1) Specifying the phenomenon to be investigated (such as gender role stereotyping), (2) Selecting the media from which the observations are to be made (such as the Caldecott Medal books for specified time periods), (3) Formulating exhaustive and mutually exclusive coding categories so that the verbal or symbolic content can be counted (such as the categories in which gender role stereotyping could occur), (4) Deciding on the sampling plan to be used in order to obtain a representative sample of the documents (such as the sample consisting of all the Caldecott winners for two 2-year periods). You might decide to look at three issues per week of a newspaper over a period of 1 year, for instance, or every issue of a week, (5) Training the coders so that they can consistently apply the coding scheme that has been developed and thus contribute to the reliability of the content analysis. Some coding is not so straightforward but may require inferences about whether a minority group, for example, is being portrayed positively or negatively. Several coders should be able to code the documents using the scheme and obtain consistent results. If the interrater reliability is satisfactory, you can proceed to the next step. If it is less than satisfactory, the coders may be useful in revising the category definitions to make them clearer and more complete, dan (6) Analyzing the data, which may involve just the frequencies and percentages in the various categories or may involve more descriptive accounts. Sumber data penelitian ini adalah Dokumen yang berupa perangkat pembelajaran mata kuliah Intensive Reading, yaitu Rencana Pembelajaran Semester dan Buku Ajar (Textbook). Teknik pengumpulan data penelitian ini menggunakan teknik analisis dokumen yang berupa pengumpulan perangkat pembelajaran berupa Rencana Pembelajaran Semester dan Buku Ajar (Textbook). Menurut Ary, Jacobs, dan Razavieh (2010), berikut ini merupakan teknik analisis data penelitian kualitatif: (1) Familiarization and Organization, (2) Coding and Reducing process, dan (3) Interpreting and Representing

\section{HASIL DAN PEMBAHASAN}

A. Rencana Pembelajaran Semester (RPS)

1. Struktur Rencana Pembelajaran Semester (RPS)

Peraturan Menteri Riset, Teknologi, dan Pendidikan Tinggi (Permenristekdikti) No. 44 tahun 2015 pasal 12 No. 3 bahwa Rencana pembelajaran semester (RPS) atau istilah lain paling sedikit memuat: (a) nama program studi, nama dan kode mata 
kuliah, semester, sks, nama dosen pengampu; (b) capaian pembelajaran lulusan yang dibebankan pada mata kuliah; (c) kemampuan akhir yang direncanakan pada tiap tahap pembelajaran untuk memenuhi capaian pembelajaran lulusan; (d) bahan kajian yang terkait dengan kemampuan yang akan dicapai; (e) metode pembelajaran; (f) waktu yang disediakan untuk mencapai kemampuan pada tiap tahap pembelajaran; (g) pengalaman belajar mahasiswa yang diwujudkan dalam deskripsi tugas yang harus dikerjakan oleh mahasiswa selama satu semester; (h) kriteria, indikator, dan bobot penilaian; dan (i) daftar referensi yang digunakan. Struktur mata kuliah Intensive Reading memuat seluruh kriteria tersebut diatas dengan urutan yang sistematis dan berisikan konten sesuai dengan ketentuan yang berlaku.

\section{Konten Rencana Pembelajaran Semester (RPS) \\ a. Capaian Pembelajaran Lulusan (CPL)}

Sesuai dengan Peraturan Menteri Riset, Teknologi, dan Pendidikan Tinggi (Permenristekdikti) No 44 tahun 2015 Bagian Kedua tentang Standar Kompetensi Lulusan pasal 05 no 03 bahwa Rumusan capaian pembelajaran lulusan sebagaimana dimaksud pada ayat (1) wajib mengacu pada deskripsi capaian pembelajaran lulusan KKNI dan memiliki kesetaraan dengan jenjang kualifikasi pada KKNI. Sesuai dengan kurikulum program studi Pendidikan Bahasa Inggris UNISRI, mata kuliah Intensive Reading memiliki capaian pembelajaran (CP) lulusan nya adalah "mahir berbahasa Inggris lisan dan tulisan dalam konteks keseharian/umum, akademis, dan pekerjaan setara tingkat Post-intermediate".

Mengacu pada Peraturan Presiden (PP) no 8 tahun 2012 tentang kerangka kualifikasi nasional Indonesia bahwa CP lulusan tersebut merupakan termasuk deskripsi jenjang KKNI level tiga (3) bagian pertama yaitu "Mampu melaksanakan serangkaian tugas spesifik, dengan menerjemahkan informasi dan menggunakan alat, berdasarkan sejumlah pilihan prosedur kerja, serta mampu menunjukkan kinerja dengan mutu dan kuantitas yang terukur, yang sebagian merupakan hasil kerja sendiri dengan pengawasan tidak langsung".

b. Capaian Pembelajaran Mata Kuliah Intensive Reading

Capaian pembelajaran (CP) mata kuliah Intensive Reading adalah "mahasiswa mampu memahami makna dan langkah-langkah retorika didalam teks essay berbentuk teks descriptive, recount, and report didalam kehidupan sehari-hari baik didalam bentuk teks otentik maupun non-otentik". CP mata kuliah tersebut sesuai dengan deskripsi jenjang KKNI level 3 bagian pertama dan kedua, bagian pertama sudah tertulis diatas sedangkan bagian kedua adalah sebagai berikut: "memiliki pengetahuan operasional yang lengkap, prinsip-prinsip serta konsep umum yang terkait dengan fakta bidang keahlian tertentu, sehingga mampu menyelesaikan berbagai masalah yang lazim dengan metode yang sesuai".

c. Kemampuan Akhir yang diharapkan

Sesuai dengan Permenristekdikti No 44 tahun 2015 Pasal 12 No. 3 c bahwa RPS paling sedikit memuat diantaranya "kemampuan akhir yang direncanakan pada tiap tahap pembelajaran untuk memenuhi capaian pembelajaran lulusan". Di dalam RPS perkuliahan ini telah berisi hal tersebut, semisal pada pertemuan pertama dan kedua yang berbunyi "Memahami makna dan langkahlangkah retorika dengan bahasa tulis yang lancar, akurat, dan berterima dalam essay yang berbentuk Descriptive".

d. Bahan kajian yang terkait dengan kemampuan yang akan dicapai

Sesuai dengan Peraturan Menteri Riset, Teknologi, dan Pendidikan Tinggi (Permenristekdikti) No 44 tahun 2015 
Bagian Ketiga tentang Standar Isi Pembelajaran Pasal 9 bahwa Tingkat kedalaman dan keluasan materi pembelajaran sebagaimana dimaksud pada ayat (1) sebagai berikut: lulusan program diploma empat dan sarjana paling sedikit menguasai konsep teoritis bidang pengetahuan dan keterampilan tertentu secara umum dan konsep teoritis bagian khusus dalam bidang pengetahuan dan keterampilan tersebut secara mendalam. Bahan kajian pada mata kuliah Intensive Reading yaitu "essay yang berbentuk recount, descriptive, dan report. Bahan kajian tersebut mencakup aspek teoritis bidang pengetahuan sebab ketiga teks tersebut berisikan pengetahuan lintas bidang yang sudah disusun dalam sebuah buku dan bahan kajian tersebut mencakup aspek ketrampilan membaca yaitu mengidentifikasi ide pokok, informasi terperinci, makna kosakata, dan referensi didalam teks.

e. Bentuk Pembelajaran (Metode pembelajaran/Model/Pengalaman Belajar)

Sesuai dengan Permenristekdikti No 44 tahun 2015 Pasal 14 No. 05 bahwa bentuk pembelajaran sebagaimana dimaksud pada ayat (4) dapat berupa: (a) kuliah, (b) responsi dan tutorial, (c) seminar; dan (d) praktikum, praktik studio, praktik bengkel, atau praktik lapangan. Pada mata kuliah Intensive Reading

f. Waktu yang disediakan untuk mencapai kemampuan pada tiap tahap pembelajaran;

Sesuai dengan Permenristekdikti No 44 tahun 2015 Pasal 12 No. 3 f bahwa RPS paling sedikit memuat diantaranya "waktu yang disediakan untuk mencapai kemampuan pada tiap tahap pembelajaran". Dan untuk RPS mata kuliah Intensive Reading telah memut waktu perkuliahan.

g. Pengalaman belajar mahasiswa yang diwujudkan dalam deskripsi tugas yang harus dikerjakan oleh mahasiswa selama satu semester;

Sesuai dengan Permenristekdikti No 44 tahun 2015 Pasal 12 No. 3 g bahwa RPS paling sedikit memuat diantaranya pengalaman belajar mahasiswa yang diwujudkan dalam deskripsi tugas yang harus dikerjakan oleh mahasiswa selama satu semester. Di dalam RPS mata kuliah Intensive Reading sudah memuat hal tersebut.

h. Kriteria, indikator, dan bobot penilaian; dan

Sesuai dengan Permenristekdikti No 44 tahun 2015 Pasal 12 No. 3 h bahwa RPS paling sedikit memuat diantaranya kriteria, indikator, dan bobot penilaian. Untuk RPS mata kuliah Intensive Reading sudah berisi Kriteria, indikator, dan bobot penilaian, diantaranya berisi (jenis) Latihan tertulis, latihan lisan, (Indikator) Latihan, lisan, dan partisipasi, dan bobot (5\%).

i. Daftar referensi yang digunakan

Sesuai dengan Permenristekdikti No 44 tahun 2015 Pasal 12 No. 3 i bahwa RPS paling sedikit memuat diantaranya Daftar referensi yang digunakan. Untuk RPS mata kuliah Intensive Reading sudah berisi i. Daftar referensi yang digunakan, yaitu Baigent Maggie. 2005. Natural English: Reading Writing Skills Intermediate Resource Book. Oxford. Oxford University Press; Beatrice S. Mikulecky, and Linda Jeffries. 2007. Advanced Reading Power: Extensive Reading, Vocabulary Building, Comprehension Skills, Reading Faster. New York. Pearson Education; Harmer Jeremy and Carol Lethaby. 2005. Just Reading and Writing. London: Marshal Cavendish Education; dan Jil and Charles Hadfield. 1995. Reading Games: A Collection of Reading Games and Activities for Intermediate to Advanced Students of English: London. Longman

\section{KESIMPULAN}

Struktur dan substansi rencana pembelajaran semester merupakan bentuk 
perencanaan yang bertujuan untuk mempersiapkan perkuliahan Intensive Reading sesuai dengan standar DIKTI dan KKNI seperti tertuang dalam Peraturan Presiden (PP) no 8 tahun 2012 tentang kerangka kualifikasi nasional Indonesia dan Peraturan Menteri Riset, Teknologi, dan Pendidikan Tinggi (Permenristekdikti) No 44 tahun 2015, sehingga penyusunan struktur dan penulisan konten berdasarkan kedua peraturan tersebut merupakan hal yang mutlak untuk dilaksanakan. Kesesuaian struktur RPS dengan standar dikti memuat 9 kriteria minimal yang sudah dipenuhi oleh RPS mata kuliah Intensive Reading. Substansi RPS mata kuliah ini sudah mencakup seluruh standar yang disebutkan didalam kedua peraturan diatas.

\section{DAFTAR PUSTAKA}

Peraturan Presiden (PP) no 8 tahun 2012 tentang kerangka kualifikasi nasional Indonesia

Peraturan Menteri Riset, Teknologi, dan Pendidikan Tinggi (Permenristekdikti) No 44 tahun 2015

Brown, H. D. 2010. Language Assessment: Principles and Classroom Practices. New York: Addison Wesley Longman, Inc.

Grabe, William and Stoller, L. Fredericka. 2002. Teaching and Research Reading. London: Longman

Hariyanto. 2010. Macam-Macam Teori Belajar.

http://belajarpsikologi.com/macammacam-teori-belajar/

Karlina Hardiyana. 2015. Analisis BBM 1 tentang

Pengajaran Membaca.

https://karlinahardiana.wordpress.c om/2015/05/16/analisis-bbm-1tentang-prinsip-prinsip-pengajaranmembaca/

Reading Techniques. 2016. http://campusconnect.infosys.com/
homedownloads/BE_old/Readin g\%20 Technique.pdf.

Sahandri, M., Ghorbani, M. R., \& Saifuddin Kumar B Abdullah (2009). The impact of electronic communication technology on written language. US-China Education Review Journal, 6(11), 25-79

Shavelson, R. and P. Stern. 1981. Research on teachers' pedagogical thoughts, judgments, decisions and behavior. Review of Educational Research, 51, 4, 455-98.

Thomas, M. M. (2001). Proficient reader characteristics: Relationships among textdependent and higherorder literacy variables with reference to stage theories of intellectual development (Order No. 3010626). Available from ProQuest Dissertations \& Theses Full Text. (304706119). Retrieved from http://search.proquest.com/docview 304706119? accountid=6143

Turkan, Sultan and Megan, SchrammPossinger. 2014. Teaching Content to English Learners in the Era of the Common Core Standards. ETS Research \& Development Educational Testing Service Rosedale Road, 19-T Princeton, NJ. 